\title{
THE GEOLOGY OF THE NEIGHBOURHOOD OF BROADFORD, SKYE.*
}

\author{
BY ALFRED HARKER, M.A., F.R.S. \\ (keal July gth, rom.) \\ I.-GENERAL RELATIONS.
}

THE Broadford district occupies the narrowest part of the Isle of Skye, dividing the Sleat district to south-east, composed of Torridonian and other ancient rocks, from the large tract to the north and west, which is chiefly made by igneous rocks of Tertiary age.

The coast of Broadford Bay is everywhere of Lower Lias strata, but is fringed by an extensive raised beach, on which the string of crofter townships stands. From the middle of the bay the Lias extends southward as a strip I to $1 / 2$ mile wide, which curves away towards the west, and terminates on the opposite coast in Rudha Suisnish, the headland between Lochs Slapin and Eishort. This strip has a synclinal structure. On the east its escarpment overlooks the main Torridonian tract. On the other side it is succeeded by the sharp anticline of Ben Suardal and Beinn an Dubhaich, where the old rocks are brought up again (Fig. I 7 ). Here are both Torridon Sandstone and Cambrian Limestones, the former resting on the latter, as is their relation throughout this district, in consequence of a great overthrust. The surface of overthrust is itself bent by the folding, and the Cambrian makes the crest of Ben Suardal, the Torridonian dipping away on the flanks. The anticline subsides towards Broadford, where the Lias passes round its end. Followed in the other direction, the axis curves away westward, as was remarked for the Liassic syncline. Here its core is made by the elongated granite boss of Beinn an Dubhaich, an intrusion of Tertiary age (Fig. I 8).

Farther west the geological relations are of a more complicated kind. About I mile west of Broadford the Lias is cut off by a north-south fault, which brings up the Cambrian Limestones. It is connected with the Beinn na Caillich intrusion, to be noticed below, and it curves away to north-west, following for some distance the shore of the Sound of Scalpa. In the other direction the fault runs obliquely along Strath Suardal, crosses the Ben Suardal anticline as a sharp monoclinal fold, and is traceable again to the south. The floor of Strath Suardal is made chiefly by the Cambrian Limestones, but immediately north-west and west of Loch Kilchrist these are

* Advance copies of this paper were issued to members in connection with the Long Excursion of rgir. 
pierced by a large volcanic vent, of Tertiary age, from which the beds dip steeply away.

The most conspicuous object seen from Broadford is Beinn na Cailich $(2,403 \mathrm{ft}), 2 \mathrm{I} / 2$ miles to the west. This and the adjoining hills are made by a large mass of Tertiary granite, and immediately north-east of this the lower slopes are made by a gabbro, intruded through the limestones at a slightly earlier time. This plutonic centre is a place of relative upheaval, and the curved axes of folding already noticed seem to be related to the same peculiar scheme of crust-movements. The north-west boundary of the granite is a fault, which dies out in each direction ; and it has let down a patch of the Tertiary basalt lavas, which have thus been preserved from destruction (Fig. I8).

\section{II.-THE OLDER ROCKS.}

Torridonian.-The Torridon Sandstone of this district is usually a reddish felspathic sandstone. Some detached areas about Creag Strollamus, north-west of Broadford, are of a more siliceous nature, and pass locally into quartzite. All the Torridonian strata in the district are overthrust, and rest on Cambrian Limestones.

Cambrian.-A small patch of the basal Cambrian Quartzite is seen, resting on Torridon Sandstone, on the south side of Allt Leth Slighe, 4 miles from Broadford (Fig. r8).

The Cambrian Limestones of this district fall into two groups. The lower, which covers much of Strath Suardal and partly surrounds the Beinn an Dubhaich granite, is characterized by abundant sponge-forms, usually preserved partly in chert. It is in most places dolomitized, and has then a massive habit and sugary texture. The upper group, well seen on Ben Suardal and about Kilbride and Torran, is often full of worm-casts, and contains many small black cherts. It is less frequently dolomitized. Near the Beinn an Dubhaich granite, and near the gabbro north-west of Broadford, the limestones are highly metamorphosed. The marble was long ago quarried near Kilchrist, and working has recently been resumed on a large scale.

\section{III.-MESOZOIC ROCKS.}

Triassic and Rhatic. - The Lias is in most places underlain by representatives of the Trias, which, however, may be wanting owing to faulting or overlap. The chief member is a conglomerate containing pebbles of Torridon Sandstone and Cambrian rocks 
Beinn na Caillich.

$\mathrm{N} .60^{\circ} \mathrm{W}$.

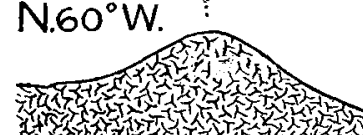

SEALEVEL

Fig. i7.-Section from Beinn na Caillich, through Ben Suardal and Cnoc Cárnach.-A. Harker.

\section{Kyle of
Scalpay.}

\section{N. $5^{\circ} \mathrm{W}$.}

\section{$O x$}

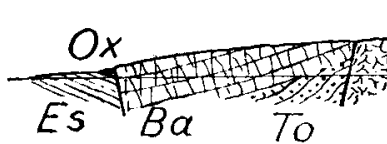

Es $B a$
Beinn na Caillich.
Beinn an Dubbaich.

\section{Loch Kilchrist.}

S. $5^{\circ} \mathrm{E}$.

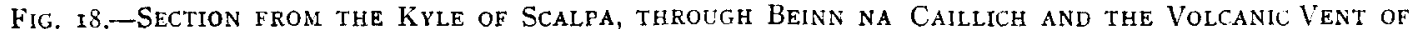
KILChrist, TO GLEN BORERAIG. $-A$. Harker.

To, Torridon Sandstone ; $O$, Cambrian Quartzite ; $C_{I}$, Cambrian Limestone, lower zone ; $C_{2}$, upper zone; $T r . T$ Trias $\mathrm{Li}$, Lower Lias; Es, Estuarine Series; Ox, Oxfordian; Ba, Basalt Lavas (Tertiary); $4 g$, Volcanic Agglomerate; $G r$, Granite and Granophyre.

(The scale of the sections is one inch to a mile. 
(limestone, chert, and quartzite). It is sometimes succeeded by greenish and red sandstones and marls. In certain places a few feet of limestone intervene between Trias and Lias, and have yielded fossils probably referable to the Rhætic. The nearest locality is in Allt a' Mhuilinn, above the old corn-mill.

Lower Lias. - The Lower Lias has been divided into a lower division, the Broadford Beds, and an upper, the Pabba Shales. The former is typically developed in this neighbourhood, and is well exposed on the coast between Lusa (about 4 miles to the east) and Broadford Pier. There is a generally ascending sequence, but modified about Harrabol by the north-south syncline and broken in numerous places by faults. The detailed succession will be found in the Geological Survey Memoir. Summarily it includes (I) alternations of sandstones, limestones, etc., with the Lusa coral-bed (Isastrca) in the upper part; (2) dark blue limestones, with quartz-pebbles in some bands, with the Ob Breakish coral-bed (Thecosmilia), gasteropods, Ostrea, etc. ; (3) white sandstones, conglomerates, and calcareous sandstones ; (4) earthy limestones, dark shales, and micaceous and calcareous sandstones, with Gryphae arcuata and various ammonites (Bucklandi and Semicostatus-zones). These last are well seen between the mouth of the river and the pier.

Near Rudh' an Eireannaich, the western point of the bay, the calcareous sandstones are succeeded by the Pabba Beds. These are represented by shales with harder flaggy and nodular calcareous bands, containing only poorly preserved fossils. The more highly fossiliferous beds exposed on the island of Pabba, 2 miles to north-east, seem to be wanting.

Middle Lias. - The Pabba Shales are succeeded towards Rudha na Sgianadin by sandstones, which are referred to the Scalpa Beds, better shown near Scalpa House, I $/ 2$ mile to the north.

The Upper Lias is not known in the district, nor are Oolitic or Cretaceous strata exposed very near to Broadford. The hill Glas Bheinn Bheag, about 4 miles to west-north-west, is made by a thick succession of sandstones, referred to the Inferior Oolite. They are partly metamorphosed by a large body of granite on the west side, and dip sharply to south-east. At the bridge over Allt Strollamus calcareous beds are seen in a highly metamorphosed state. A smaller burn to the east affords a section of the Great Estuarine Series, including shales with badly preserved Cyrena and bands of limestone crowded with Ostrea hebridica. There is again some metamorphism. The dip is still sharply to south-east, and higher up the stream this brings on Oxfordian beds, indurated blue shales with some belemnites in the lower part and cordate ammonites above. Finally comes about i $5 \mathrm{ft}$. thickness of Upper Cretaceous, a limestone partly silicified and 
containing fragments of Inoceramus. This is faulted against the Tertiary basalts (Fig. I 8 ).

\section{IV.-TERTIARY IGNEOUS ROCKS.}

Volcanic Rocks.-The great thickness of basaltic lavas, which makes all the north-western part of Skye, has been removed from this part of the island by the great erosion of later Tertiary time, and the only relics near Broadford have been preserved by being faulted down against the Beinn na Caillich granite. The largest area is on the north-western side (Fig. 18), and is exposed in the stream which comes down from Loch Cùil na Creig. Here the slope is not very different from the dip of the lavas. Near the little tarn is an inter-bedded river-conglomerate, largely of Torridon Sandstone pebbles. This is near the base of the group, which is seen close by resting on the Torridonian. On the southeastern side of the granite, faulted in between it and the Cambrian limestones, is a strip which includes both basalt lavas and bedded volcanic agglomerate (Fig. I 7 ).

The most interesting representative of the volcanic phase is the great volcanic vent, one and three-quarter miles across, seen above Loch Kilchrist (Fig. I8). The agglomerate which occupies it encloses blocks, large and small, of basalt and of Jurassic sandstone. On the edge of the vent is a broken ring of intrusions of a peculiar granophyre, containing partly digested relics of gabbro.

Plutonic Rocks. - Above the high road, from $\mathrm{I}$ to 2 miles northwest of Broadford, is a large irregular boss of gabbro. It breaks vertically through the Cambrian Limestones, of which it encloses many small patches, all transformed to marble.

The granite mass of Beinn na Caillich, 2 miles in diameter, also has the general habit of a boss. It is later than the gabbro, and encloses patches of this as well as of limestone and basalt. Another granite boss, 3 miles long from east to west, breaking through the Cambrian Limestones, makes the hill Beinn an Dubhaich.

Minor Intrusions.-- Of later intrusion than the plutonic rocks are a vast number of sills and dykes, mostly of no great dimensions. They include both acid and basic examples, the former belonging to a somewhat early stage, anterior to the chief faulting. Some sills of spherulitic granophyre are well exposed on the coast west of Rudh' an Eireannaich. More remarkable are the composite sills of the Heast Road, Cnoc Càrnach, Beinn a' Chàirn, etc., intruded mostly in the Lias along the curved syncline. These consist of basalt at top and bottom with granophyre in the middle. In a peculiar composite sill at Rudh' an Eireannaich 
the middle rock is a bostonite, and there is a gradual passage into the basalt. Simple basic sills are not uncommon in the Lias, but are mostly of no great thickness. Of basic dykes there is a great profusion and variety. Many make prominent objects in the Lias of the coast near Broadford and in the Cambrian Limestones of Ben Suardal and the Strath.

\section{REFERENCES.}

The district is included in Sheet 7r (Glenelg) of the Geological Survey Map of Scotland (one inch to a mile), colour-printed, I910, price 2s. 6d. The explanatory memoir to accompany the map is "The Geology of Glenelg, Lochalsh, and South-East part of Skye," I9Io, price 3s. 6d. The Tertiary igneous rocks are fully treated in a special memoir of the Geological Survey, "The Tertiary Igneous Rocks of Skye," I904, price 9s. These works contain full bibliographies of the voluminous literature of the district, and it will suffice here to select a few of the chief items.

KING, W., and RownEY, T. H.- "On the Geological Age and Microscopic Structure of the Serpentine Marble or Ophite of Skye." Proc. Rov. Ir. Acad. (2), vol. i, pp. I40-153; I871.

Zrrket., F. - "Geologische Skizze von der Westküste Schot:lands." Zeits. Deuts. Geol. Ges., vol. xxiii, pp. I-I24; 187I.

BRYCE, J.- "On the Jurassic Rocks of Skye and Raasay." With a Palæontological Appendix by R. TATE. Quart. Fourn. Geol. Soc., vol. xxix, pp. 317-351 ; 1873 .

JudD, J. W.-."The Secondary Rocks of Scotland. Second paper. On the Ancient Volcanoes." Quart. Fourn. Geol. Soc., vol. xxx, pp. 220-30I ; 1874. "Third Paper. The Strata of the Western Coast and Islands." Itid., vol. xxxiv, pp. 660-74I ; 1878.

GEIKIE, SIR A.- "On the Age of the Altered Limestone of Strath, Skye," Quart. Fourn. Geol. Soc., vol. xliv, pp. 62-73; 1888. "The History of Volcanic Action during the Tertiary Period in the British Isles." Trans. Roy. Soc. Edin., vol, xxxv, pp. $2 \mathrm{I}-\mathrm{I} 84$; I888. Also many references in "The Ancient Volcanoes of Great Britain," vol. ii ; 1897.

HARKER, A.- "On certain Granophyres, modified by the Incorporation of Gabbro-Fragments, in Strath (Skye)." Quart. Fourn. Geol. Soc., vol. lii, pp. 320-328; I 896 .

A Relief-Model of Central Skye, by R. F. Gwinnell, is exhibited in the Museum of Practical Geology, Jermyn Street. 